\title{
Regulation of TPD52 by antitumor microRNA-218 suppresses cancer cell migration and invasion in lung squamous cell carcinoma
}

\author{
TOMOHIRO KUMAMOTO $^{1}$, NAOHIKO SEKI ${ }^{2}$, HIROKO MATAKI $^{1}$, KEIKO MIZUNO $^{1}$, KAZUTO KAMIKAWAJI $^{1}$, \\ TAKUYA SAMUKAWA ${ }^{1}$, KEIICHI KOSHIZUKA ${ }^{2}$, YUSUKE GOTO $^{2}$ and HIROMASA INOUE ${ }^{1}$ \\ ${ }^{1}$ Department of Pulmonary Medicine, Graduate School of Medical and Dental Sciences, \\ Kagoshima University, Kagoshima 890-8520; ${ }^{2}$ Department of Functional Genomics, Chiba \\ University Graduate School of Medicine, Chuo-ku, Chiba 260-8670, Japan
}

Received June 21, 2016; Accepted August 19, 2016

DOI: 10.3892/ijo.2016.3690

\begin{abstract}
The development of targeted molecular therapies has greatly benefited patients with lung adenocarcinomas. In contrast, these treatments have had little benefit in the management of lung squamous cell carcinoma (lung SCC). Therefore, new treatment options based on current genomic approaches are needed for lung SCC. Aberrant microRNA (miRNA) expression has been shown to promote lung cancer development and aggressiveness. Downregulation of microRNA-218 (miR-218) was frequently observed in our miRNA expression signatures of cancers, and previous studies have shown an antitumor function of $m i R-218$ in several types of cancers. However, the impact of $m i R-218$ on lung SCC is still ambiguous. The present study investigated the antitumor roles of $m i R$-218 in lung SCC to identify the target genes regulated by this miRNA. Ectopic expression of $m i R-218$ greatly inhibited cancer cell migration and invasion in the lung SCC cell lines EBC-1 and SK-MES-1. Through a combination of in silico analysis and gene expression data searching, tumor protein D52 (TPD52) was selected as a putative target of $m i R-218$ regulation. Moreover, direct binding of $m i R-218$ to the 3'-UTR of TPD52 was observed by dual luciferase reporter assay. Overexpression of TPD52 was observed in lung SCC clinical specimens, and knockdown of TPD52 significantly suppressed cancer cell migration and invasion in lung SCC cell lines. Furthermore, the downstream pathways mediated by TPD52 involved critical regulators of genomic stability and mitotic checkpoint genes. Taken together, our data showed that downregulation of $m i R-218$ enhances overexpression of
\end{abstract}

Correspondence to: Professor Hiromasa Inoue, Department of Pulmonary Medicine, Graduate School of Medical and Dental Sciences, Kagoshima University, 8-35-1 Sakuragaoka, Kagoshima 890-8520, Japan

E-mail: inoue-pulm@umin.net

Key words: microRNA, miR-218, tumor-suppressor, TPD52, lung squamous cell carcinoma
TPD52 in lung SCC cells, promoting cancer cell aggressiveness. Identification of tumor-suppressive miRNA-mediated RNA networks of lung SCC will provide new insights into the potential mechanisms of the molecular pathogenesis of the disease.

\section{Introduction}

Lung cancer remains the most frequent cause of cancerrelated death in developed countries (1). Approximately $80 \%$ of lung cancers are categorized as non-small cell lung cancer (NSCLC), and NSCLC is divided into four major subtypes pathologically: adenocarcinoma, squamous cell carcinoma (SCC), large cell carcinoma and neuroendocrine cancer (2). Development of targeted molecular therapies has remarkably improved the overall survival of patients with adenocarcinoma (3-6). In contrast, targeted molecular therapies have offered few benefits in the management of lung SCC (7). Therefore, there is a need for effective treatment options based on current genomic approaches for lung SCC.

After the human genome sequencing era, the discovery of an extremely large number of non-coding RNAs conceptually transformed cancer research. MicroRNAs (miRNAs) are small non-coding RNAs involved in the repression or degradation of target RNA transcripts in a sequence-dependent manner $(1,2)$. The ability of miRNAs is unique; a single miRNA may regulate a vast number of protein-coding or non-coding RNAs in human cells. Therefore, aberrantly expressed miRNAs may upset tightly regulated cellular RNA networks. This failing of the RNA network contributes to cancer development, aggressiveness and drug resistance (3-5). In fact, aberrantly expressed miRNAs have been reported in various types of human cancers, including lung SCC (6-8). Based on miRNA expression signatures, we identified tumor-suppressive miRNAs and the cancer RNA networks regulated by these miRNAs (9-11). We hypothesize that elucidation of tumor-suppressive miRNAregulated oncogenic networks will provide new insights into the potential molecular mechanisms of lung SCC.

In our earlier studies determining miRNA expression signatures, we showed that miRNA-218 was significantly 
downregulated in several types of cancer tissues (12-15). Our previous studies also demonstrated that downregulation of $m i R-218$ enhanced overexpression of extracellular matrix (ECM) protein components or actin-related proteins, and this promoted cancer cell migration and invasion (16-18). Tumorsuppressive roles of $m i R-218$ were reported in several types of cancer. However, the impact of $m i R-218$ on lung SCC remains ambiguous.

The aim of the present study was to investigate the functional significance of $m i R-218$ in lung SCC and to identify molecular targets regulated by this miRNA. We found that restoration of $m i R-218$ significantly suppressed cancer cell migration and invasion. Using luciferase reporter assay, tumor protein D52 (TPD52) was shown to be directly regulated by $m i R$-218. Overexpression of TPD52 was observed in lung SCC clinical specimens and downregulation of the TPD52 gene significantly inhibited cancer cell aggressiveness. $m i R-218 /$ TPD52-regulated RNA networks may provide new insights into the potential mechanisms of lung SCC pathogenesis.

\section{Materials and methods}

Clinical specimens, cancer cell lines and RNA extraction. In all, 31 lung SCC specimens and 24 non-cancerous lung specimens were obtained from patients who underwent thoracic surgery at Kagoshima University Hospital from 2010 to 2013. The present study was approved by the Institutional Review Board for Clinical Research of the Kagoshima University School of Medicine. Prior written informed consent and approval were obtained from each patient. Table I describes the patient background and clinical characteristics of collected specimens. Samples were staged using the TNM scheme according to the International Association for the Study of Lung Cancer and were graded histologically (19). These archival formalin-fixed paraffin-embedded (FFPE) samples were subsequently studied by qRT-PCR analysis and immunohistochemistry as previously described (9-11).

The human lung SCC cell lines EBC-1 and SK-MES-1 were acquired from the Japanese Cancer Research Resources Bank (Osaka, Japan) and the American Type Culture Collection ATCC; Manassas, VA, USA), respectively.

Total RNA was isolated using Isogen II (code no: 311-07361; Nippon Gene, Co., Ltd., Tokyo, Japan) as directed by the manufacturer.

Quantitative reverse transcription PCR ( $q R T-P C R)$. PCR quantification was performed as previously described (9-11). The expression of $m i R-218$ was determined using stem-loop RT-PCR as directed by the manufacturer (P/N: 000521; Applied Biosystems, Foster City, CA, USA). The TaqMan probe and TPD52 primers were from Assay-on-Demand ${ }^{\mathrm{TM}}$ Gene Expression products (P/N: Hs00893105_m1; Applied Biosystems). For quantification, miRNA and mRNA data were normalized against human $R N U 48$ (P/N: 001006; Applied Biosystems) and GUSB (P/N: Hs99999908_m1; Applied Biosystems), respectively.

Transfection of mature miRNA and small interfering RNA (siRNA). Pre-miR ${ }^{\mathrm{TM}}$ miRNA precursors for $m i R-218$ ( $h s a-m i R$ 218-5p, P/N: AM1 7100; Applied Biosystems) and negative
Table I. Characteristics of the lung cancer and non-cancerous cases.

A, Characteristics of the lung cancer cases

\begin{tabular}{lcc}
\hline Lung cancer patients & $\mathrm{n}$ & $(\%)$ \\
\hline Total no & 31 & \\
Median age (range) & $70(50-88)$ & $(93.5)$ \\
Gender & & $(6.5)$ \\
Male & 29 & \\
Female & 2 & $(12.9)$ \\
Pathological stage & & $(29.0)$ \\
IA & 4 & $(12.9)$ \\
IB & 9 & $(16.1)$ \\
IIA & 4 & $(25.8)$ \\
IIB & 5 & $(3.2)$ \\
IIIA & 8 & $\mathrm{n}$ \\
IIIB & 1 & 24 \\
\hline B, Characteristics of the non-cancerous cases & \\
\hline Non-cancerous tissues & & $(50-88)$ \\
\hline Total number & & \\
Median age (range) & & \\
Gender & & \\
Male & & \\
Female & & \\
\hline
\end{tabular}

control miRNA (P/N: AM 17111; Applied Biosystems), Stealth Select RNAi siRNA, si-TPD52 (P/N: HSS120730 and HSS120731; Invitrogen, Carlsbad, CA, USA), and negative control siRNA (P/N: 4390843; Invitrogen) were used in this study. EBC-1 and SK-MES-1 cells in Opti-MEM medium (cat. no. 31985070; Thermo Fisher Scientific, Waltham, MA, USA) were transfected with Lipofectamine RNAiMAX transfection reagent (P/N: 56532; Invitrogen) with $10 \mathrm{nM}$ mature miRNA or siRNA.

Cell proliferation, migration and invasion assays. Cell proliferation was determined by XTT assay using Cell Proliferation kit (SKU: 20-300-1000; Biological Industries, Kibbutz Beit Haemek, Israel). Cell migration activity was analyzed by wound-healing assay, and cell invasion was analyzed using Corning BioCoat Matrigel Invasion chamber (cat. no. 354480; BD Biosciences, Bedford, MA, USA). The cell proliferation, migration, and invasion assays were carried out as previously described (9-11).

Identification of putative miR-218 target genes in lung $S C C$ cells. Genome-wide gene expression analysis of $m i R$-218-transfected EBC-1 cells was performed (accession number: GSE77790). Putative $m i R$-218-regulated genes were identified by searching the TargetScan database (http://www. targetscan.org/). We then examined the expression levels 
of putative $m i R-218$ targets in lung SCC clinical expression data from the GEO database (accession number: GSE19188). Oligo-microarray procedures and data mining methods were conducted as previously described $(20,21)$.

Western blot analysis. Cells were harvested $96 \mathrm{~h}$ after transfection, and proteins were extracted from lysed cells. Protein lysates $(20 \mu \mathrm{g})$ were separated on NuPAGE $4-12 \%$ Bis-Tris gels (cat. no. NP0323BOX; Invitrogen) before transfer of proteins to a polyvinylidene fluoride membrane. Immunoblotting was performed using diluted primary anti-TPD52 antibodies (1:250 dilution; Human Protein Atlas no. HPA028427; Atlas Antibodies, Stockholm, Sweden) and anti-GAPDH antibodies (1:10,000 dilution; cat. no. MAB374; Chemicon International, Inc., Temecula, CA, USA). These assays were carried out as previously described (9-11).

Plasmid construction and dual-luciferase reporter assay. The procedure for the dual-luciferase reporter assay was previously described (9-11). A partial sequence of the wild-type TPD52 3'-UTR containing the $m i R-218$ target site or the TPD52 3'-UTR partial sequence lacking the $m i R$ - 218 target site was cloned into the psiDHECK-2 vector between the XhoI-PmeI restriction sites in the 3'-UTR of the hRluc gene (cat. no. C8021; Promega, Madison, WI, USA).

Immunohistochemistry. The expression status of TPD52 in lung SCC clinical specimens (BC04002; US Biomax, Inc., Rockville, MD, USA) was confirmed via immunohistochemistry using an UltraVision Detection system (cat. no. TP-015-HD, Thermo Fisher Scientific) according to the manufacturer's protocol. Tissues were incubated with primary rabbit polyclonal anti-TPD52 antibodies (1:3,000 dilution; HPA028427) then treated with biotinylated goat anti-rabbit secondary antibodies. Antibodies were visualized using diaminobenzidine hydrogen peroxidase as the chromogen, and slides were counterstained with $0.5 \%$ hematoxylin.

Identification of downstream targets regulated by TPD52 in lung SCC. Gene expression analysis using si-TPD52-transfected EBC-1 cells identified molecular targets regulated by TPD52 in lung SCC cells. Microarray expression profiles of si-TPD52 transfectants were compiled and deposited into the GEO database (accession number: GSE82108).

Statistical analysis. RT-PCR results were analyzed using Mann-Whitney $U$ tests to evaluate the relationships between the 2 groups, while Bonferroni-adjusted Mann-Whitney U tests were used to analyze the relationships among three or more variables. All analyses were performed using Expert StatView (version 5; SAS Institute Inc., Cary, NC, USA).

\section{Results}

Expression of miR-218 in lung SCC tissues and cell lines. To confirm the miRNA expression signatures of lung SCC cells, we evaluated the expression level of $m i R-218$ in lung SCC tissues $(n=31)$ and non-cancerous lung tissues $(n=24)$. The patient clinicopathological features are summarized in Table I. The expression level of $m i R-218$ was significantly
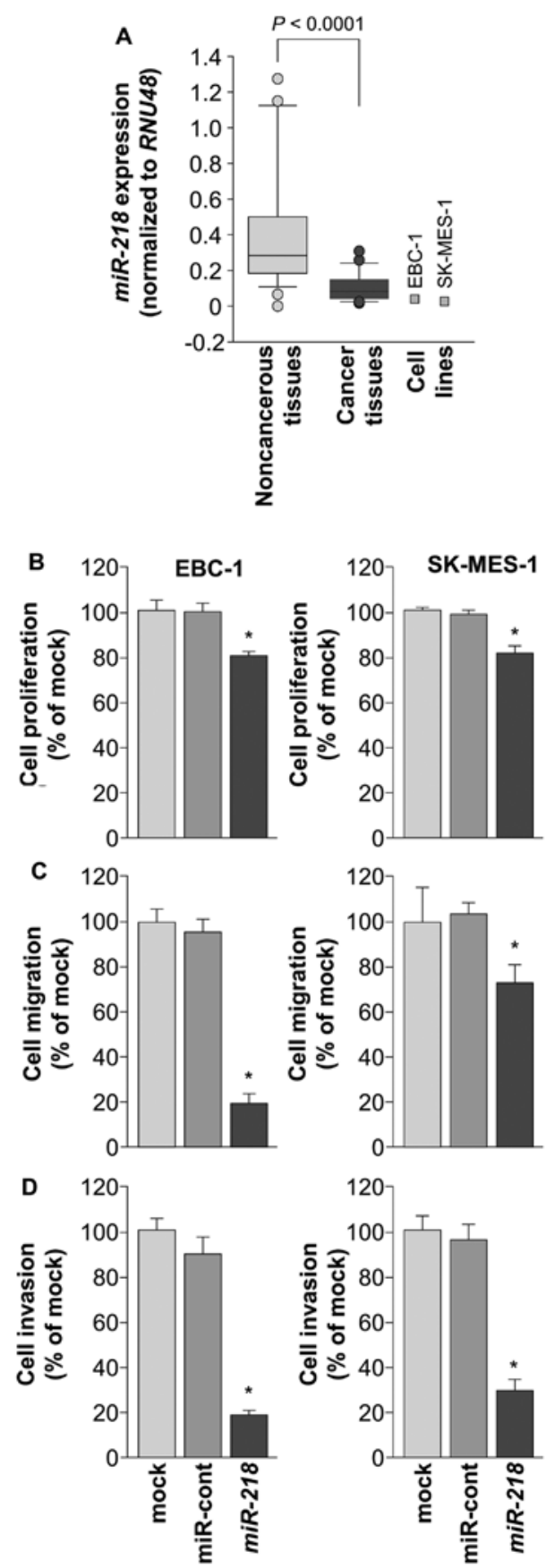

Figure 1. The expression of $m i R-218$ in lung SCC and its ectopic effects on EBC-1 and SK-MES-1 cancer cell lines. (A) Expression levels of $m i R-218$ in lung SCC clinical specimens and cell lines (EBC-1 and SK-MES-1) were determined using qRT-PCR. Data were normalized to RNU48 expression. (B) Cell growth was determined using XTT assays $72 \mathrm{~h}$ after transfection with $10 \mathrm{nM} \mathrm{miR-218}$. $^{*} \mathrm{P}<0.0001$. (C) Cell migration activity was determined using wound-healing assays. ${ }^{*} \mathrm{P}<0.0001$. (D) Cell invasion activity was determined using Matrigel invasion assays. ${ }^{*} \mathrm{P}<0.0001$.

downregulated in cancer tissues compared to non-cancerous tissues ( $\mathrm{P}<0.0001$; Fig. 1A). Expression of $m i R-218$ in EBC-1 and SK-MES-1 cell lines was also lower than in non-cancerous lung tissues (Fig. 1A).

Effects of miR-218 restoration on the proliferation, migration and invasion of EBC-1 and SK-MES-1 cells. To investigate the antitumor activity of $m i R-218$, we performed gain-of-function 


\begin{tabular}{|c|} 
Identification of $\mathbf{m i R}-218$ target genes \\
\hline Gene expression analysis \\
miR-218 transfection into EBC-1 cells \\
$\left(\log _{2}\right.$ ratio $\left.<-1.0\right)$ \\
(GSE: 77790$)$ \\
513 genes \\
\hline \\
TargetScan Database \\
(release 7.0) \\
Prediction of putative \\
miR-218 target genes \\
163 genes \\
\\
\\
\hline \\
Gene expression analysis \\
(GSE: 19188 ) \\
NCSLC upregulated genes \\
(fold change $>1.5$ ) \\
36 genes \\
Table II
\end{tabular}

Figure 2. Flow chart illustrating the analysis strategy for $m i R-218$ target genes in lung SCC cells. assays using miRNA transfection into EBC-1 and SK-MES-1 cells. Cell proliferation assays showed that cancer cell growth was slightly inhibited in $m i R-218$ transfectants compared with mock- or miR control-transfected EBC-1 and SK-MES-1 cells (Fig. 1B). Cancer cell migration and invasion activities were significantly inhibited in $m i R-218$ transfectants compared with mock- or miR-control-transfectants $(\mathrm{P}<0.0001$; Fig. $1 \mathrm{C}$ and $\mathrm{D})$.

Identification of putative targets regulated by $m i R-218$ in $E B C-1$ cells. To identify putative targets of $m i R-218$, we employed a combination of in silico analysis, genome-wide gene expression analysis and analysis of gene expression in clinical specimens using the GEO database. First, we identified 513 genes downregulated by $m i R-218$ transfection into EBC-1 cells $\left(\log _{2}\right.$ ratio <-1.0). Among these 513 genes, 163 genes have putative miR-218 binding sites in their 3'-UTR regions according to the TargetScan database. Next, we crossreferenced these genes with genes upregulated (fold change $>1.5$ ) in NSCLC clinical specimens from the GEO gene expression data set (accession number: GSE19188). A total of
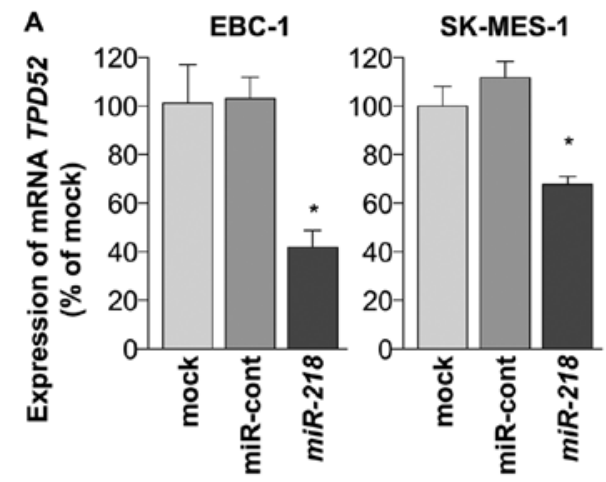

B
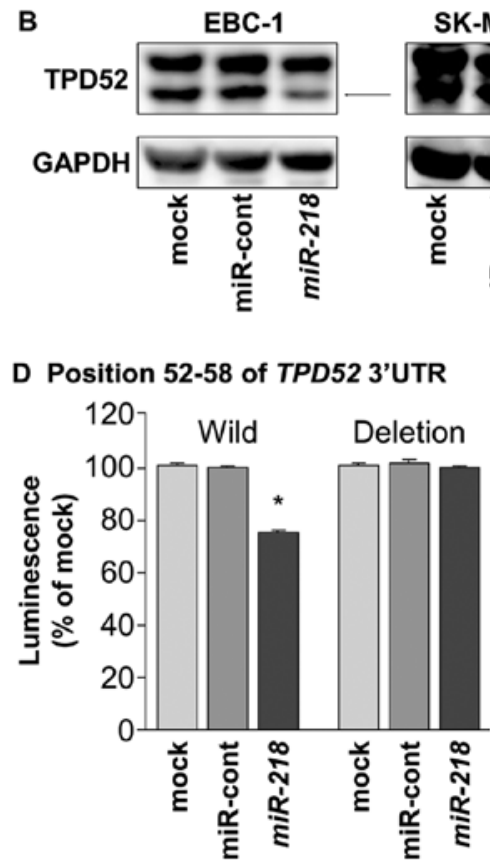

\section{Position 52-58 of TPD52 3'UTR}

\begin{tabular}{|c|c|}
\hline $\begin{array}{l}5 \text { - - CUGCAAGCGAGGUCCAAGCACAU - - - 3' } \\
3 \text { - - - UGUACCAAUCUAGUU'II'I'II' - -5' }\end{array}$ & \\
\hline 5- - CUGCAAGCGAGGUCC - - - - - U - - 3' & Deletion type \\
\hline
\end{tabular}

Position 778-784 of TPD52 3'UTR

\begin{tabular}{|c|c|}
\hline 5- - AUAACAUUCUGAAUCAAGCACAC - - -3' & Wild-type \\
\hline 3- - - UGUACCAAUCUAGUUCGUGUU - - -5' & $\operatorname{miR}-218$ \\
\hline 5- - AUAACAUUCUGAAUC - - - C C - - 3' & Deletion type \\
\hline
\end{tabular}

Position 940-946 of TPD52 3'UTR

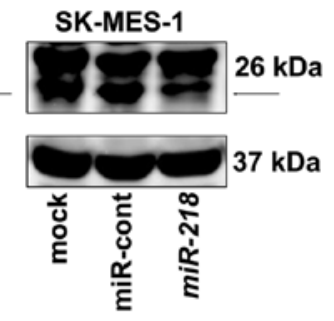

\begin{tabular}{|c|c|}
\hline $\begin{array}{l}5 \text { - - AGCCACUAUUUAAAAAUAAGCACAC - - 3' } 1111111111 \\
3 \text { - - - - UGUACCAAUCUAGUUCGUGUU - - 5' }\end{array}$ & $\begin{array}{l}\text { Wild-type } \\
\text { miR-218 }\end{array}$ \\
\hline 5- AGCCACUA - & Deletion type \\
\hline
\end{tabular}

\section{E Position 778-784 of TPD52 3'UTR}

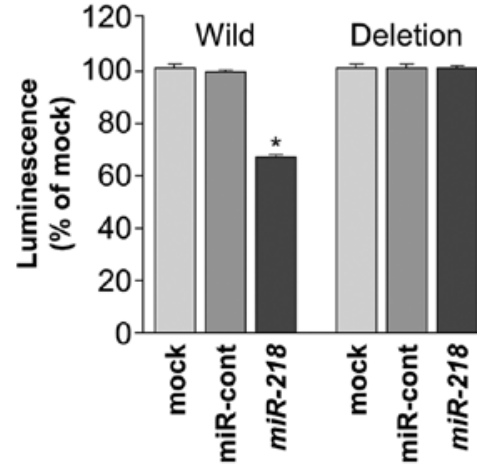

\section{F Position 940-946 of TPD52 3'UTR}

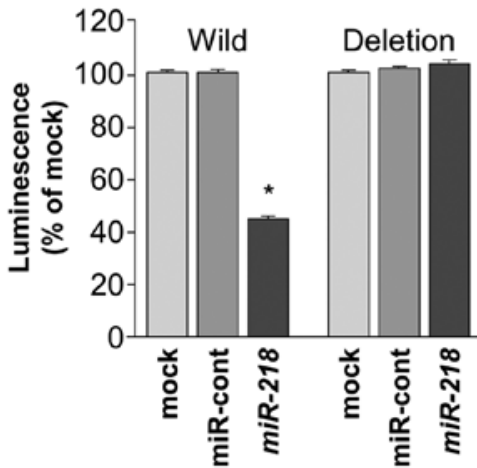

Figure 3. Direct regulation of TPD52 by miR-218 in lung SCC cells. (A) TPD52 mRNA expression was evaluated by qRT-PCR in EBC-1 and SK-MES-1 cells $72 \mathrm{~h}$ after transfection with miR-218. GUSB was used as an internal control. "P<0.0001. (B) TPD52 protein expression in EBC-1 and SK-MES-1 cells was evaluated using western blotting $72 \mathrm{~h}$ after transfection with $m i R$-218. GAPDH was used as a loading control. (C) Putative $m i R$-218 binding sites in the 3 '-UTR of TPD52 mRNA. (D-F) Dual luciferase reporter assays using vectors encoding putative miR-218 target sites in the TPD52 3'-UTR for both wild-type and deleted regions. Normalized data were calculated as Renilla/firefly luciferase activity ratios. ${ }^{*} \mathrm{P}<0.0001$. 
Table II. Downregulated genes in $m i R-218$ tranfectant.

\begin{tabular}{|c|c|c|c|c|c|c|c|}
\hline \multirow[b]{2}{*}{$\begin{array}{l}\text { Entrez } \\
\text { gene } \\
\text { ID }\end{array}$} & \multirow[b]{2}{*}{$\begin{array}{l}\text { Gene } \\
\text { symbol }\end{array}$} & \multirow[b]{2}{*}{ Description } & \multicolumn{3}{|c|}{$m i R-218$ target site } & \multirow{2}{*}{$\begin{array}{c}\text { EBC-1 } \\
\text { miR-218 } \\
\text { transfectant } \\
\left(\log _{2}\right. \\
\text { ratio })\end{array}$} & \multirow{2}{*}{$\begin{array}{c}\text { GSE: } \\
19188 \\
\text { (fold } \\
\text { change) }\end{array}$} \\
\hline & & & Total & $\begin{array}{l}\text { Conserved } \\
\text { site }\end{array}$ & $\begin{array}{l}\text { Poorly } \\
\text { conserved } \\
\text { site }\end{array}$ & & \\
\hline 7163 & TPD52 & Tumor protein D52 & 4 & 2 & 2 & -1.33 & 2.66 \\
\hline 5563 & PRKAA2 & $\begin{array}{l}\text { Protein kinase, AMP-activated, } \\
\alpha 2 \text { catalytic subunit }\end{array}$ & 4 & 0 & 4 & -1.04 & 2.50 \\
\hline 2673 & GFPT1 & Glutamine-fructose-6-phosphate transaminase 1 & 4 & 1 & 3 & -1.17 & 1.92 \\
\hline 332 & BIRC5 & Baculoviral IAP repeat containing 5 & 2 & 0 & 2 & -2.05 & 12.42 \\
\hline 56938 & ARNTL2 & $\begin{array}{l}\text { Aryl hydrocarbon receptor nuclear } \\
\text { translocator-like } 2\end{array}$ & 2 & 0 & 2 & -1.09 & 7.85 \\
\hline 112399 & EGLN3 & Egl-9 family hypoxia-inducible factor 3 & 2 & 1 & 1 & -1.45 & 5.97 \\
\hline 84181 & CHD6 & chromodomain helicase DNA binding protein 6 & 2 & 1 & 1 & -1.35 & 2.30 \\
\hline 29927 & SEC61A1 & Sec61 $\propto 1$ subunit (S. cerevisiae) & 2 & 1 & 1 & -1.09 & 2.13 \\
\hline 8776 & MTMRI & Myotubularin related protein 1 & 2 & 1 & 1 & -1.06 & 1.96 \\
\hline 131566 & $D C B L D 2$ & Discoidin, CUB and LCCL domain containing 2 & 2 & 2 & 0 & -1.46 & 1.88 \\
\hline 2820 & GPD2 & $\begin{array}{l}\text { Glycerol-3-phosphate dehydrogenase } 2 \\
\text { (mitochondrial) }\end{array}$ & 2 & 0 & 2 & -1.02 & 1.83 \\
\hline 399694 & SHC4 & $\begin{array}{l}\text { SHC (Src homology } 2 \text { domain containing) } \\
\text { family, member } 4\end{array}$ & 2 & 1 & 1 & -1.25 & 1.58 \\
\hline 3486 & $I G F B P 3$ & Insulin-like growth factor binding protein 3 & 1 & 0 & 1 & -2.09 & 4.12 \\
\hline 144406 & WDR66 & WD repeat domain 66 & 1 & 0 & 1 & -1.11 & 2.98 \\
\hline 25907 & TMEM158 & Transmembrane protein 158 (gene/pseudogene) & 1 & 0 & 1 & -1.12 & 2.96 \\
\hline 10447 & FAM3C & Family with sequence similarity 3 , member C & 1 & 1 & 0 & -2.08 & 2.90 \\
\hline 4017 & LOXL2 & Lysyl oxidase-like 2 & 1 & 0 & 1 & -1.96 & 2.56 \\
\hline 9139 & $C B F A 2 T 2$ & $\begin{array}{l}\text { Core-binding factor, runt domain, } \alpha \text { subunit } 2 \text {; } \\
\text { translocated to, } 2\end{array}$ & 1 & 0 & 1 & -1.11 & 2.42 \\
\hline 3691 & ITGB4 & Integrin, $\beta 4$ & 1 & 0 & 1 & -1.12 & 2.20 \\
\hline 6745 & SSRI & Signal sequence receptor, $\alpha$ & 1 & 1 & 0 & -1.47 & 1.92 \\
\hline 1457 & CSNK2A1 & Casein kinase $2, \alpha 1$ polypeptide & 1 & 1 & 0 & -1.30 & 1.90 \\
\hline 157638 & $F A M 84 B$ & Family with sequence similarity 84 , member B & 1 & 0 & 1 & -1.02 & 1.90 \\
\hline 949 & SCARB1 & Scavenger receptor class B, member 1 & 1 & 0 & 1 & -1.54 & 1.84 \\
\hline 2011 & $M A R K 2$ & MAP/microtubule affinity-regulating kinase 2 & 1 & 1 & 0 & -1.41 & 1.75 \\
\hline 9289 & GPR56 & G protein-coupled receptor 56 & 1 & 0 & 1 & -1.53 & 1.70 \\
\hline 55959 & SULF2 & Sulfatase 2 & 1 & 0 & 1 & -1.11 & 1.67 \\
\hline 65985 & $A A C S$ & Acetoacetyl-CoA synthetase & 1 & 0 & 1 & -1.10 & 1.63 \\
\hline 160 & $A P 2 A 1$ & Adaptor-related protein complex $2, \alpha 1$ subunit & 1 & 1 & 0 & -1.14 & 1.63 \\
\hline 54928 & IMPADI & Inositol monophosphatase domain containing 1 & 1 & 1 & 0 & -1.01 & 1.62 \\
\hline 1889 & ECE1 & Endothelin converting enzyme 1 & 1 & 0 & 1 & -1.55 & 1.61 \\
\hline 55609 & ZNF280C & Zinc finger protein $280 \mathrm{C}$ & 1 & 1 & 0 & -1.10 & 1.61 \\
\hline 6533 & SLC6A6 & $\begin{array}{l}\text { Solute carrier family } 6 \\
\text { (neurotransmitter transporter), member } 6\end{array}$ & 1 & 1 & 0 & -1.13 & 1.61 \\
\hline 80000 & GREBIL & $\begin{array}{l}\text { Growth regulation by estrogen in } \\
\text { breast cancer-like }\end{array}$ & 1 & 0 & 1 & -1.15 & 1.59 \\
\hline 10776 & ARPP19 & cAMP-regulated phosphoprotein, $19 \mathrm{kDa}$ & 1 & 1 & 0 & -1.33 & 1.52 \\
\hline 83637 & ZMIZ2 & Zinc finger, MIZ-type containing 2 & 1 & 1 & 0 & -1.59 & 1.52 \\
\hline 79139 & DERL1 & Derlin 1 & 1 & 0 & 1 & -1.16 & 1.51 \\
\hline
\end{tabular}

36 candidate genes were identified as putative target genes of miR-218 regulation in lung SCC (Table II). Fig. 2 shows our strategy for selecting putative $m i R-218$ target genes.
In the present study, we focused on the TPD52 gene, investigating TPD52 function and downregulated TPD52-mediated pathways. 

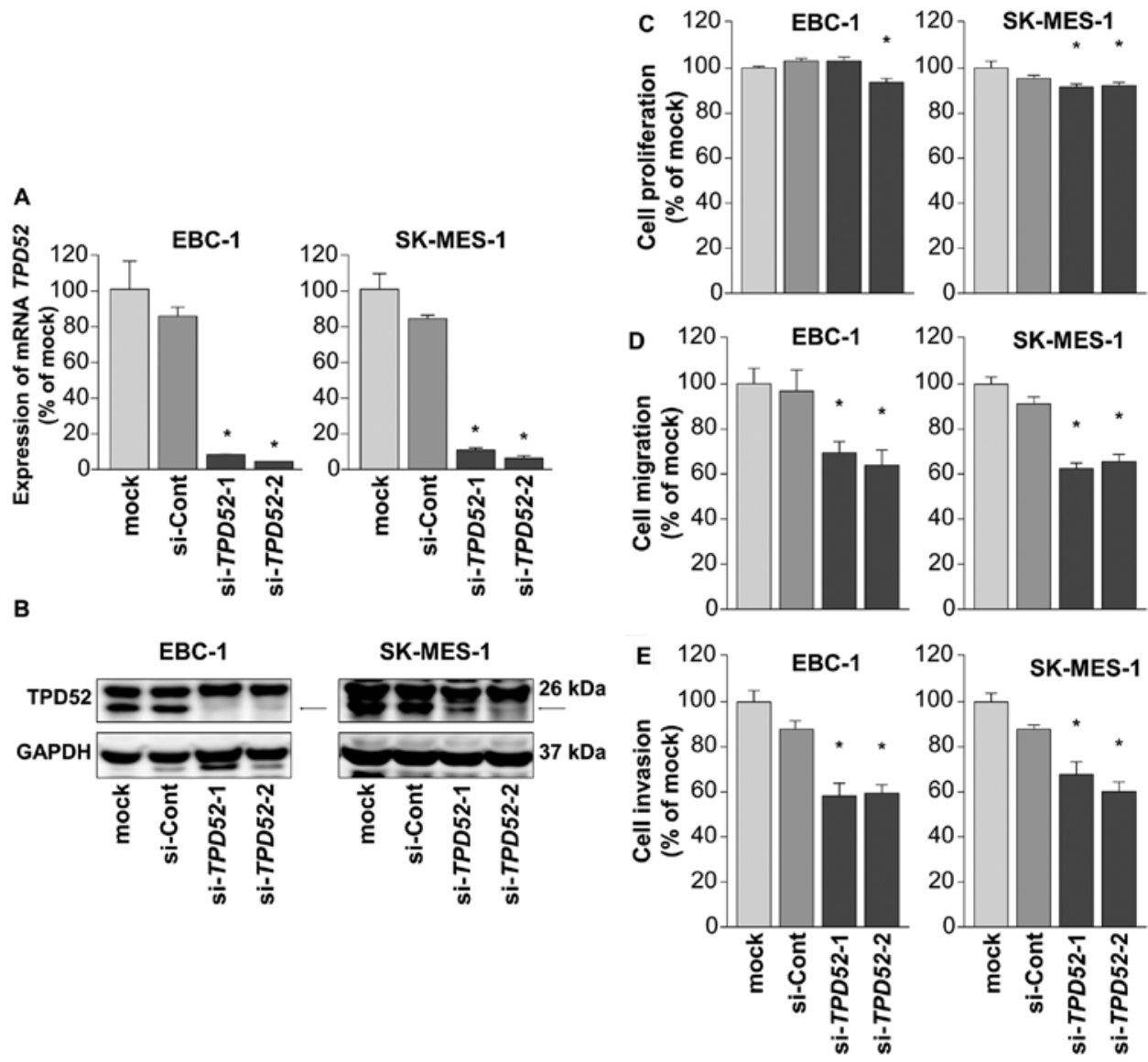

Figure 4. Effects of TPD52 silencing in lung SCC cell lines. (A) TPD52 mRNA expression in EBC-1 and SK-MES-1 cells was evaluated by qRT-PCR $72 \mathrm{~h}$ after transfection with si-TPD52-1 and si-TPD52-2. GUSB was used as an internal control. (B) TPD52 protein expression in EBC-1 and SK-MES-1 cells was evaluated by western blot analysis $72 \mathrm{~h}$ after transfection with $m i R-218$. GAPDH was used as a loading control. (C) Cell proliferation was determined using XTT assays $72 \mathrm{~h}$ after transfection with $10 \mathrm{nM}$ si-TPD52-1 or si-TPD52-2. "P $<0.0001$. (D) Cell migration activity was determined by wound-healing assays. ${ }^{*} \mathrm{P}<0.0001$. (E) Cell invasion activity was determined using Matrigel invasion assays. ${ }^{*} \mathrm{P}<0.0001$.

TPD52 is directly targeted by miR-218 in lung SCC cells. First, we measured the expression of TPD52/TPD52 using quantitative RT-PCR and western blotting to determine whether restoration of $m i R-218$ in EBC-1 and SK-MES-1 cells suppressed the expression of TPD52/TPD52. As shown in Fig. 3A and B, the expression levels of TPD52/TPD52 were markedly repressed by $m i R-218$ transfection compared with mock- or miR-control-transfected cells.

Next, we used luciferase reporter assays to determine whether $m i R-218$ directly binds to the 3'-UTR of TPD52 mRNA. We used vectors encoding either partial wild-type sequences of the 3'-UTR of TPD52 including the predicted miR-218 target sites (positions 52-58, 778-784, 940-946 of the TPD52 3'-UTR), or deletion vectors lacking these sites (Fig. 3C). The luminescence intensities were significantly reduced by transfection with $m i R-218$ and the vector carrying the wild-type 3'-UTR of TPD52, whereas transfection with the deletion vector blocked the decrease of luminescence in EBC-1 cells $(\mathrm{P}<0.0001)$. Thus, $m i R-218$ bound directly to three sites in the 3'-UTR of TPD52 (Fig. 3D-F).

Effects of TPD52 silencing on cell proliferation, migration and invasion in lung SCC cell lines. We performed loss-offunction studies using si-TPD52 to investigate the oncogenic function of TPD52 in lung SCC cells. First, we measured the knockdown efficiency of si-TPD52 transfection in EBC-1 and SK-MES-1 cells. RT-PCR and western blotting showed that two siRNAs (si-TPD52-1 and si-TPD52-2) could effectively reduce the expression of TPD52/TPD52 in EBC-1 and SK-MES-1 cells (Fig. 4A and B).

Next, we carried out functional assays using these two siRNAs. XTT assays demonstrated that cell proliferation was inhibited by si-TPD52 transfection only in SK-MES-1 cells (Fig. 4C). Cell migration and invasion activities were significantly inhibited by si-TPD52 transfection in both EBC-1 and SK-MES-1 cells in comparison with mock- or negative-control transfectants (Fig. 4D and E).

TPD52 was strongly expressed in clinical lung SCC specimens. To analyze whether TPD52 was upregulated in lung SCC clinical specimens, we carried out immunohistochemical staining of lung SCC and non-cancerous lung tissues. Thirty specimens were stained in this study (20 lung SCC specimens and 10 non-cancerous tissues); all lung SCC specimens stained moderately or strongly, whereas all non-cancerous specimens stained weakly or negatively for TPD52 (Table III and Fig. 5).

Identification of TPD52-mediated downstream pathways in lung SCC cells. To identify the downstream genes regulated by TPD52, genome-wide gene expression analysis and in silico 
Table III. Immunohistochemistry status and characteristics of the lung cancer and non-cancerous cases.

A, Immunohistochemistry status and characteristics of the lung squamous cell carcinoma cases

\begin{tabular}{ccccccc}
\hline $\begin{array}{l}\text { Patient } \\
\text { no. }\end{array}$ & Grade & T & N & M & $\begin{array}{c}\text { Pathological } \\
\text { stage }\end{array}$ & $\begin{array}{c}\text { Immuno- } \\
\text { histochemistry }\end{array}$ \\
\hline 1 & 1 & 3 & 1 & 0 & IIIa & $(++)$ \\
2 & 1 & 3 & 0 & 0 & IIIa & $(++)$ \\
3 & 2 & 2 & 1 & 0 & II & $(++)$ \\
4 & 2 & 3 & 0 & 0 & IIIa & $(++)$ \\
5 & 1 & 2 & 0 & 0 & I & $(++)$ \\
6 & 1 & 2 & 1 & 0 & II & $(+)$ \\
7 & 1 & 3 & 1 & 0 & IIIa & $(+++)$ \\
8 & 1 & 2 & 0 & 0 & I & $(++)$ \\
9 & 1 & 2 & 1 & 0 & II & $(++)$ \\
10 & 1 & 2 & 0 & 0 & I & $(++)$ \\
11 & 2 & 2 & 2 & 0 & IIIa & $(+++)$ \\
12 & 2 & 2 & 0 & 0 & I & $(+)$ \\
13 & 2 & 1 & 0 & 0 & I & $(++)$ \\
14 & 2 & 1 & 0 & 0 & I & $(++)$ \\
15 & 2 & 2 & 1 & 0 & II & $(+)$ \\
16 & 2 & 3 & 1 & 0 & III & $(++)$ \\
17 & 2 & 2 & 0 & 0 & I & $(++)$ \\
18 & 2 & 2 & 1 & 0 & II & $(+)$ \\
19 & 2 & 3 & 2 & 0 & IIIa & $(+++)$ \\
20 & 2 & 2 & 0 & 0 & I & $(++)$ \\
\hline
\end{tabular}

$\mathrm{B}$, Immunohistochemistry status of non-cancerous cases

\begin{tabular}{lc}
\hline Patient no. & Immunohistochemistry \\
\hline 91 & $(-)$ \\
92 & $(+)$ \\
93 & $(+)$ \\
94 & $(-)$ \\
95 & $(-)$ \\
96 & $(-)$ \\
97 & $(-)$ \\
98 & $(+)$ \\
99 & $(+)$ \\
100 & $(+)$ \\
\hline
\end{tabular}

analysis were performed in lung SCC cells transfected with si-TPD52. A total of 2,278 genes were identified as downregulated in si-TPD52-transfected EBC-1 cells compared with the control $\left(\log _{2}\right.$ ratio $\left.<-0.5\right)$. Among them, 215 genes were upregulated in NSCLC specimens in the GEO database (accession number: GSE19188). We categorized the 215 genes according to KEGG pathways, and 7 pathways were identified as significantly enriched pathways (Table IV). Fig. 6 shows our strategy for selecting TPD52-mediated downstream pathways. Among
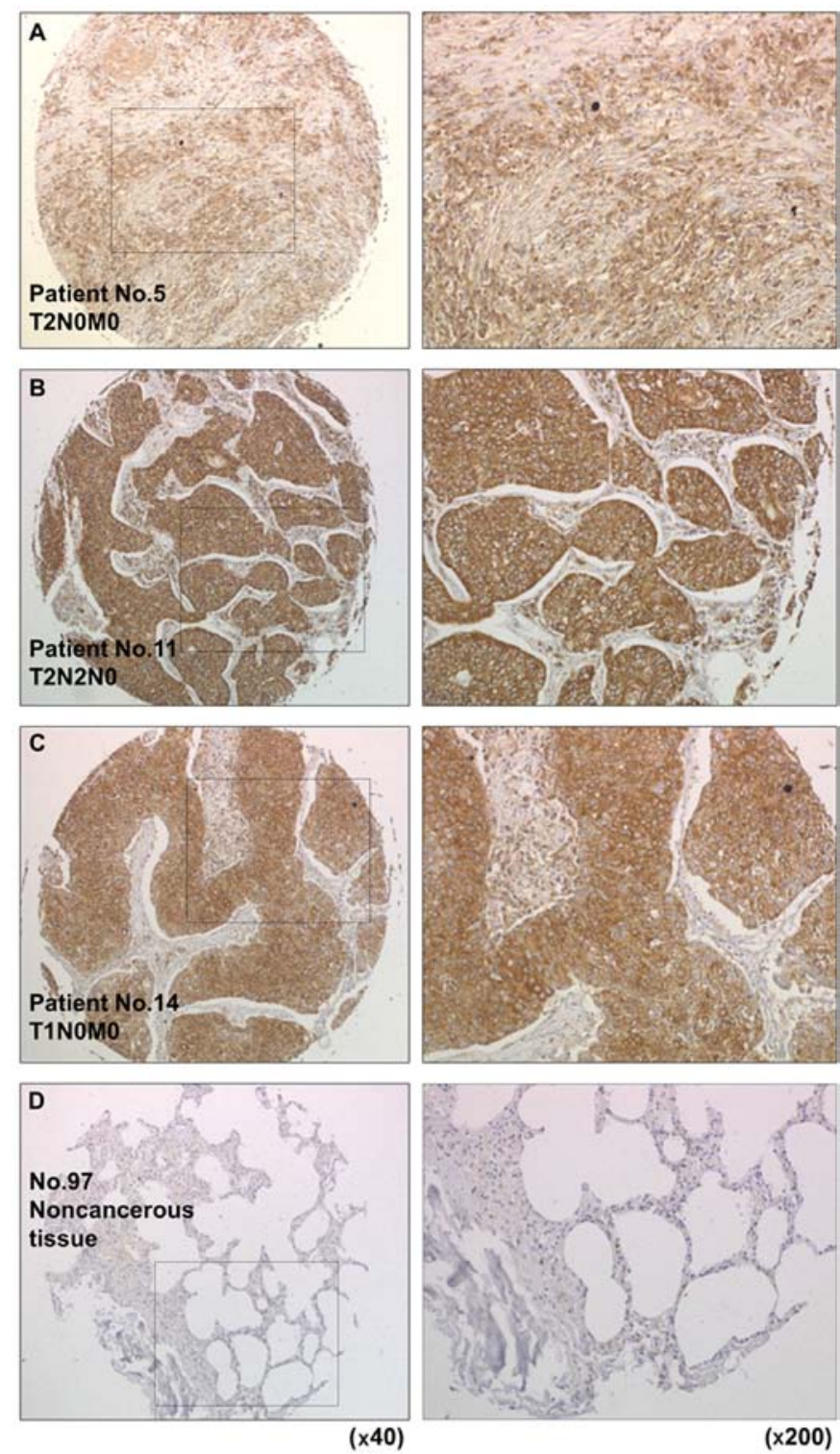

Figure 5 (A-D). Immunohistochemical staining of TPD52 in lung SCC specimens. Differences in TPD52 expression were observed between cancer lesions and non-cancerous tissues in the same field. Normal lung specimens stained weakly or negatively for TPD52.

these pathways, we focused on the 'Cell cycle pathway', 'DNA replication pathways' and 'p53 signaling pathway'. Genes involved in these pathways are listed in Table V.

\section{Discussion}

A single miRNA can regulate an extremely large number of protein-coding or non-coding RNAs. Thus, aberrant expression of miRNAs disrupts the RNA network in cancer cells. Identification of aberrantly expressed miRNAs and the novel cancer networks they regulate is a research trend of the postgenome-sequencing era. Recent evidence shows that disruption of normally-regulated RNA networks by aberrantly expressed miRNAs triggers cancer cell development, progression and metastasis $(3,4)$. Our recent studies of miRNA expression signatures in various cancers indicated that $m i R-218$ is frequently downregulated in cancers (9-11). Investigating 
Table IV. Significantly enriched annotations regulated by si-TPD52-1 and si-TPD52-2 in lung SCC cells.

\begin{tabular}{lll}
\hline No. of genes & P-value & \multicolumn{1}{c}{ Annotations } \\
\hline 12 & $2.06 \mathrm{E}-11$ & (KEGG) 04110: Cell cycle \\
8 & $8.84 \mathrm{E}-07$ & (KEGG) 04114: Oocyte meiosis \\
7 & $2.27 \mathrm{E}-06$ & (KEGG) 05322: Systemic lupus erythematosus \\
5 & $5.41 \mathrm{E}-06$ & (KEGG) 03030: DNA replication \\
6 & $2.30 \mathrm{E}-05$ & (KEGG) 04914: Progesterone-mediated oocyte maturation \\
5 & $9.53 \mathrm{E}-05$ & (KEGG) 04115: p53 signaling pathway \\
2 & $4.91 \mathrm{E}-02$ & (KEGG) 03410: Base excision repair \\
\hline
\end{tabular}

Table V. Representative pathways identified as downstream of TPD52.

\begin{tabular}{|c|c|c|}
\hline \multicolumn{3}{|c|}{ Cell cycle pathway } \\
\hline Gene symbol & Description & GSE:19188 ( $\log _{2}$ ratio $)$ \\
\hline$T T K$ & TTK protein kinase & 3.23 \\
\hline$B U B 1$ & Budding uninhibited by benzimidazoles 1 homolog (yeast) & 3.21 \\
\hline$C C N B 2$ & Cyclin B2 & 3.20 \\
\hline MCM4 & Minichromosome maintenance complex component 4 & 3.13 \\
\hline$C C N B 1$ & Cyclin B1 & 2.82 \\
\hline PLK1 & Polo-like kinase 1 & 2.81 \\
\hline$C D C 25 C$ & Cell division cycle 25 homolog $\mathrm{C}$ (S. pombe) & 2.77 \\
\hline$C D K 1$ & Cyclin-dependent kinase 1 & 2.40 \\
\hline CCNE2 & Cyclin E2 & 2.04 \\
\hline DBF4 & DBF4 homolog (S.cerevisiae) & 1.42 \\
\hline MCM6 & Minichromosome maintenance complex component 6 & 1.31 \\
\hline BUB3 & Budding uninhibited by benzimidazoles 3 homolog (yeast) & 1.07 \\
\hline
\end{tabular}

DNA replication pathway

Gene symbol

Description

GSE: $19188\left(\log _{2}\right.$ ratio)

\begin{tabular}{lll}
\hline MCM4 & Minichromosome maintenance complex component 4 & 3.13 \\
FEN1 & Flap structure-specific endonuclease 1 & 1.66 \\
MCM6 & Minichromosome maintenance complex component 6 & 1.31 \\
PRIM1 & Primase, DNA, polypeptide 1 (49 kDa) & 1.25 \\
POLA2 & Polymerase (DNA directed), $\alpha 2$ (70 kD subunit) & 1.00
\end{tabular}

p53 signaling pathway

\begin{tabular}{llr}
\hline Gene symbol & \multicolumn{1}{c}{ Description } & GSE: 19188 (log ratio $)^{-}$ \\
\hline$C C N B 2$ & Cyclin B2 & 3.20 \\
$C C N B 1$ & Cyclin B1 & 2.82 \\
GTSE1 & G-2 and S-phase expressed 1 & 2.79 \\
$C D K 1$ & Cyclin-dependent kinase 1 & 2.40 \\
$C C N E 2$ & Cyclin E2 & 2.04
\end{tabular}

$m i R$-218-regulated RNA networks in lung SCC is the first step in construction of a new treatment strategy for the disease.

Our current data showed that expression of miR218 was significantly reduced in lung SCC specimens. The mature form of $m i R-218$ is generated from two separate loci, $m i R-218-1$ and $m i R-218-2$, which are located on chromosomes $4 \mathrm{p} 15.31$ and $5 \mathrm{q} 35.1$ within the introns of SLIT2 and SLIT3, respectively (22). Several lines of evidence suggest that $m i R-218$ is 
Identification of TPD52 downstream pathways

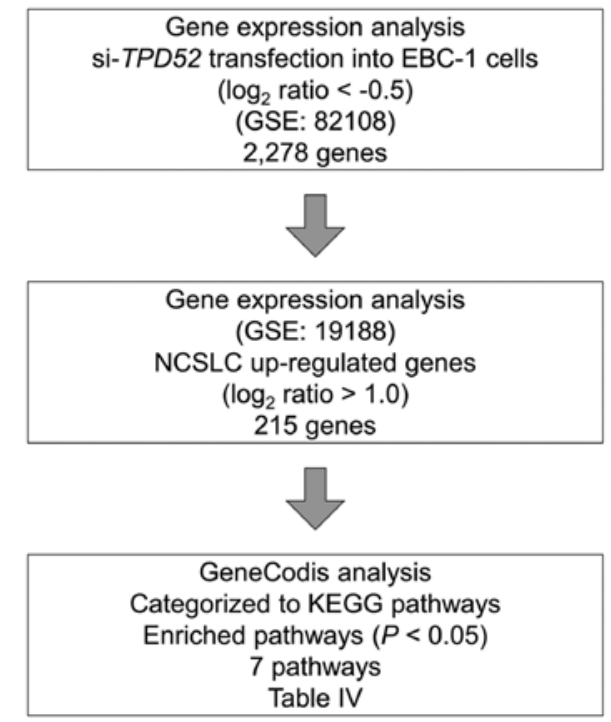

Figure 6. Flow chart illustrating the strategy for identifying TPD52-mediated downstream pathways.

frequently downregulated in various cancers $(17,18,23,24)$. In this study, ectopic expression of $m i R-218$ significantly inhibited cancer cell migration and invasion, suggesting this miRNA suppresses metastasis-promoting genes. Our previous studies showed that antitumor effects of $m i R-218$ explicitly contribute to migration and invasion in head and neck cancer, cervical cancer, renal cell carcinoma and prostate cancer $(17,18,23,24)$. Interestingly, $m i R$-218-regulated genes were involved in ECM-related components such as collagens, laminins and integrins $(17,18,23,24)$. Accumulating evidence indicates that the interaction of cancer cells with their microenvironment influences the initiation, development and metastasis of cancer cells $(25,26)$. Overexpression of ECM components and activation of ECM-integrin signaling were observed in several types of cancers and shown to activate cancer cell aggressiveness (27). The discovery of tumor-suppressive $m i R$-218-regulated genes and pathways may provide important insights into the potential mechanisms of lung SCC metastasis.

To better understand lung SCC development and metastasis, we identified $m i R$ - 218 target genes using a combination of in silico and genome-wide gene expression analyses. We have identified antitumor miRNA-regulated oncogenes and novel cancer networks using this strategy (9-11). In the present study, a total of 36 putative target genes of $m i R-218$ were identified. Among these genes, we demonstrated that LOXL2 (lysyl oxidase homolog 2) was directly regulated by $m i R-218$ in head and neck cancer and prostate cancer (28). Another group showed direct regulation of BIRC5 (baculoviral IAP repeat containing 5) by $m i R-218$ in cervical cancer (29). These findings show the effectiveness of our strategy in identifying target genes of $m i R$-218-regulation in cancer cells.

In the present study, we focused on TPD52 and investigated the functional significance of this gene in lung SCC. TPD52 was initially cloned through differential screening using a breast cancer cDNA library (30). This cDNA clone had novel sequences and was expressed in breast and basal cell carcinomas (30). Interestingly, this gene is located on the human chromosome $8 \mathrm{q} 21.13$, a frequently observed region of chromosomal amplification in several types of cancers (31-33). In lung adenocarcinoma, chromosome 8q21.13, which includes TPD52, was one of the most notable amplified genomic regions (34). A vast number of studies showed that TPD52 is overexpressed both at the mRNA and protein levels in several cancers. Likewise, overexpression of TPD52 was reported in small cell lung cancer, lung adenocarcinoma and lung SCC (35-37). The influence of smoking is important in lung cancer pathogenesis. Expression levels of TPD52 were enhanced in airway epithelial cells in smokers with lung cancer compared to smokers without cancer (38). The functional roles of TPD52 were investigated using overexpression or knockdown analytical methods. Ectopic expression of mouse TPD52 in 3T3 fibroblasts resulted in a transformed phenotype that progressed to metastasis (39). Several studies have shown that increased expression of TPD52 enhances the proliferation of prostate cancer cell lines under both normal and androgenresistant conditions $(40,41)$. Other studies showed that TPD52 knockdown increases apoptotic cell death in ERBB2-amplified breast cancer cell lines (33). These findings suggest that overexpression of TPD52 enhances cancer cell aggressiveness and contributes to several oncogenic pathways.

Recently, several studies demonstrated that TPD52 expression is regulated by several miRNAs in cancer cells. Downregulation of TPD52 expression was observed by $m i R-107$ and $m i R-185$ transfection into non-small cell lung cancer cells and $m i R-34 a$ transfection into colorectal cancer cells $(42,43)$. Our previous data showed that the tumorsuppressive $m i R$-224 directly regulates oncogenic TPD52 in prostate cancer cells, and silencing TPD52 results in significant reductions in cancer cell migration and invasion in prostate cancer cells (44). More recently, $m i R$ - 218 was shown to directly regulate TPD52 in prostate cancer cells (45). These data agree with our present report in lung SCC and support our conclusions. Control of TPD52 expression by miRNAs is a novel molecular mechanism of cancer cells, and further investigation of the miRNA-TPD52 axis is needed.

In the present study, we identified TPD52-mediated cancer pathways using genome-wide gene expression analysis of si-TPD52-transfected lung SCC cells. Our data showed that several pathways were identified downstream of TPD52 pathways, such as the 'Cell cycle pathway', 'DNA replication pathway' and 'p53 signaling pathway'. The genes involved in these pathways were critical regulators of genomic stability and were mitotic checkpoint genes $(46,47)$. The functional insights obtained in the current studies indicated that several cell cycle kinases, such as TTK, BUB1 and PLK1, were multi-functional enzymes and contributed to cancer cell migration, invasion and metastasis (48-50). The protein kinase TTK promoted the cell proliferation and migration through activation of AKT-mTOR and MDM2-p53 signaling pathways in hepatocellular carcinoma cells (48). Using the siRNA screen of the human kinome revealed that a serine/threonine kinase BUB1 acted as an essential mediator of TGF $\beta$-dependent signaling (49). This study demonstrated that BUB1 interacted with both, TGFBRI and TGFBRII and promoted the TGF $\beta$-dependent epithelial mesenchymal transition (EMT), cell migration and invasion (49). PLK1 is a serine/threonine kinase and a pivotal player of cell cycle regulator (50). Overexpression of PLK1 
was observed in prostate cancer and involved in enhancing EMT and stimulation of cell migration and invasion (50). In bladder cancer, CCNB2 was overexpressed in cancer cells and knockdown of $C C N B 2$ inhibited invasion and metastatic abilities (51). These findings have supported our present data of knockdown of TPD52 in lung cancer cells. Exploration of novel TPD52-mediated pathways may lead to the development of new treatment protocols for this disease.

In conclusion, expression of $m i R-218$ was frequently downregulated in lung SCC clinical specimens and appeared to function in anti-migration and anti-invasion roles through targeting of TPD52. Elucidation of $m i R$-218-regulated cancer networks should provide new information on potential therapeutic targets in the treatment of lung SCC development and metastasis.

\section{Acknowledgements}

We thank Dr Masami Sato (Department of General Thoracic Surgery, Graduate School of Medical and Dental Sciences, Kagoshima University, Kagoshima, Japan) for kindly providing surgically resected samples. The present study was supported in part by the Grants-in-Aid for Scientific Research from the Japan Society for the Promotion of Science (JSPS, KAKENHI grants 15K09179 and 16K19458).

\section{References}

1. Bartel DP: MicroRNAs: Genomics, biogenesis, mechanism, and function. Cell 116: 281-297, 2004.

2. Filipowicz W, Bhattacharyya SN and Sonenberg N: Mechanisms of post-transcriptional regulation by microRNAs: Are the answers in sight? Nat Rev Genet 9: 102-114, 2008.

3. Hobert O: Gene regulation by transcription factors and microRNAs. Science 319: 1785-1786, 2008.

4. Iorio MV and Croce CM: MicroRNAs in cancer: Small molecules with a huge impact. J Clin Oncol 27: 5848-5856, 2009.

5. Rolfo C, Fanale D, Hong DS, Tsimberidou AM, Piha-Paul SA, Pauwels P, Van Meerbeeck JP, Caruso S, Bazan V, Cicero G, et al: Impact of microRNAs in resistance to chemotherapy and novel targeted agents in non-small cell lung cancer. Curr Pharm Biotechnol 15: 475-485, 2014.

6. Yanaihara N, Caplen N, Bowman E, Seike M, Kumamoto K, Yi M, Stephens RM, Okamoto A, Yokota J, Tanaka T, et al: Unique microRNA molecular profiles in lung cancer diagnosis and prognosis. Cancer Cell 9: 189-198, 2006.

7. Raponi M, Dossey L, Jatkoe T, Wu X, Chen G, Fan H and Beer DG: MicroRNA classifiers for predicting prognosis of squamous cell lung cancer. Cancer Res 69: 5776-5783, 2009.

8. Moriya Y, Nohata N, Kinoshita T, Mutallip M, Okamoto T, Yoshida S, Suzuki M, Yoshino I and Seki N: Tumor suppressive microRNA-133a regulates novel molecular networks in lung squamous cell carcinoma. J Hum Genet 57: 38-45, 2012.

9. Mataki H, Enokida H, Chiyomaru T, Mizuno K, Matsushita R, Goto Y, Nishikawa R, Higashimoto I, Samukawa T, Nakagawa M, et al: Downregulation of the microRNA-1/133a cluster enhances cancer cell migration and invasion in lung-squamous cell carcinoma via regulation of Coronin1C. J Hum Genet 60: 53-61, 2015.

10. Mataki H, Seki N, Chiyomaru T, Enokida H, Goto Y, Kumamoto T, Machida K, Mizuno K, Nakagawa $M$ and Inoue $\mathrm{H}$ : Tumor-suppressive microRNA-206 as a dual inhibitor of MET and EGFR oncogenic signaling in lung squamous cell carcinoma. Int J Oncol 46: 1039-1050, 2015.

11. Mizuno K, Seki N, Mataki H, Matsushita R, Kamikawaji K, Kumamoto T, Takagi K, Goto Y, Nishikawa R, Kato M, et al: Tumor-suppressive microRNA-29 family inhibits cancer cell migration and invasion directly targeting LOXL2 in lung squamous cell carcinoma. Int J Oncol 48: 450-460, 2016.
12. Kikkawa N, Hanazawa T, Fujimura L, Nohata N, Suzuki H, Chazono H, Sakurai D, Horiguchi S, Okamoto Y and Seki N: miR-489 is a tumour-suppressive miRNA target PTPN11 in hypopharyngeal squamous cell carcinoma (HSCC). Br J Cancer 103: 877-884, 2010.

13. Hidaka H, Seki N, Yoshino H, Yamasaki T, Yamada Y, Nohata N, Fuse M, Nakagawa $M$ and Enokida H: Tumor suppressive microRNA-1285 regulates novel molecular targets: Aberrant expression and functional significance in renal cell carcinoma. Oncotarget 3: 44-57, 2012.

14. Itesako T, Seki N, Yoshino H, Chiyomaru T, Yamasaki T, Hidaka H, Yonezawa T, Nohata N, Kinoshita T, Nakagawa M, et al: The microRNA expression signature of bladder cancer by deep sequencing: The functional significance of the miR-195/497 cluster. PLoS One 9: e84311, 2014.

15. Kojima S, Enokida H, Yoshino H, Itesako T, Chiyomaru T, Kinoshita T, Fuse M, Nishikawa R, Goto Y, Naya Y, et al: The tumor-suppressive microRNA-143/145 cluster inhibits cell migration and invasion by targeting GOLM1 in prostate cancer. J Hum Genet 59: 78-87, 2014.

16. Tatarano S, Chiyomaru T, Kawakami K, Enokida H, Yoshino H, Hidaka H, Yamasaki T, Kawahara K, Nishiyama K, Seki N, et al: miR-218 on the genomic loss region of chromosome 4p15.31 functions as a tumor suppressor in bladder cancer. Int $\mathrm{J}$ Oncol 39: 13-21, 2011.

17. Kinoshita T, Hanazawa T, Nohata N, Kikkawa N, Enokida H, Yoshino H, Yamasaki T, Hidaka H, Nakagawa M, Okamoto Y, et al: Tumor suppressive microRNA-218 inhibits cancer cell migration and invasion through targeting laminin-332 in head and neck squamous cell carcinoma. Oncotarget 3: 1386-1400, 2012.

18. Yamamoto N, Kinoshita T, Nohata N, Itesako T, Yoshino H, Enokida H, Nakagawa M, Shozu M and Seki N: Tumor suppressive microRNA-218 inhibits cancer cell migration and invasion by targeting focal adhesion pathways in cervical squamous cell carcinoma. Int J Oncol 42: 1523-1532, 2013.

19. Goldstraw P, Crowley J, Chansky K, Giroux DJ, Groome PA, Rami-Porta R, Postmus PE, Rusch V and Sobin L; International Association for the Study of Lung Cancer International Staging Committee; Participating Institutions: The IASLC Lung Cancer Staging Project: Proposals for the revision of the TNM stage groupings in the forthcoming (seventh) edition of the TNM Classification of malignant tumours. J Thorac Oncol 2: 706-714, 2007.

20. Fukumoto I, Kinoshita T, Hanazawa T, Kikkawa N, Chiyomaru T, Enokida H, Yamamoto N, Goto Y, Nishikawa R, Nakagawa M, et al: Identification of tumour suppressive microRNA-451a in hypopharyngeal squamous cell carcinoma based on microRNA expression signature. Br J Cancer 111: 386-394, 2014.

21. Matsushita R, Seki N, Chiyomaru T, Inoguchi S, Ishihara T, Goto Y, Nishikawa R, Mataki H, Tatarano S, Itesako T, et al: Tumour-suppressive microRNA-144-5p directly targets CCNE1/2 as potential prognostic markers in bladder cancer. Br J Cancer 113: 282-289, 2015.

22. Lu YF, Zhang L, Waye MM, Fu WM and Zhang JF: MiR-218 mediates tumorigenesis and metastasis: Perspectives and implications. Exp Cell Res 334: 173-182, 2015.

23. Yamasaki T, Seki N, Yoshino H, Itesako T, Hidaka H, Yamada Y, Tatarano S, Yonezawa T, Kinoshita T, Nakagawa M, et al: MicroRNA-218 inhibits cell migration and invasion in renal cell carcinoma through targeting caveolin-2 involved in focal adhesion pathway. J Urol 190: 1059-1068, 2013.

24. Nishikawa R, Goto Y, Sakamoto S, Chiyomaru T, Enokida H, Kojima S, Kinoshita T, Yamamoto N, Nakagawa M, Naya Y, et al: Tumor-suppressive microRNA-218 inhibits cancer cell migration and invasion via targeting of LASP1 in prostate cancer. Cancer Sci 105: 802-811, 2014.

25. Weaver VM, Petersen OW, Wang F, Larabell CA, Briand P, Damsky C and Bissell MJ: Reversion of the malignant phenotype of human breast cells in three-dimensional culture and in vivo by integrin blocking antibodies. J Cell Biol 137: 231-245, 1997.

26. Bissell MJ and Radisky D: Putting tumours in context. Nat Rev Cancer 1: 46-54, 2001.

27. Hood JD and Cheresh DA: Role of integrins in cell invasion and migration. Nat Rev Cancer 2: 91-100, 2002.

28. Fukumoto I, Kikkawa N, Matsushita R, Kato M, Kurozumi A, Nishikawa R, Goto Y, Koshizuka K, Hanazawa T, Enokida H, et al: Tumor-suppressive microRNAs (miR-26a/b, miR-29a/b/c and miR-218) concertedly suppressed metastasis-promoting LOXL2 in head and neck squamous cell carcinoma. J Hum Genet 61: 109-118, 2016. 
29. Kogo R, How C, Chaudary N, Bruce J, Shi W, Hill RP, Zahedi P, Yip KW and Liu FF: The microRNA-218 Survivin axis regulates migration, invasion, and lymph node metastasis in cervical cancer. Oncotarget 6: 1090-1100, 2015.

30. Byrne JA, Tomasetto C, Garnier JM, Rouyer N, Mattei MG, Bellocq JP, Rio MC and Basset P: A screening method to identify genes commonly overexpressed in carcinomas and the identification of a novel complementary DNA sequence. Cancer Res 55: 2896-2903, 1995.

31. Byrne JA, Balleine RL, Schoenberg Fejzo M, Mercieca J, Chiew YE, Livnat Y, St Heaps L, Peters GB, Byth K, Karlan BY, et al: Tumor protein D52 (TPD52) is overexpressed and a gene amplification target in ovarian cancer. Int J Cancer 117: 1049-1054, 2005.

32. Rubin MA, Varambally S, Beroukhim R, Tomlins SA, Rhodes DR Paris PL, Hofer MD, Storz-Schweizer M, Kuefer R, Fletcher JA, et al: Overexpression, amplification, and androgen regulation of TPD52 in prostate cancer. Cancer Res 64: 3814-3822, 2004.

33. Roslan N, Bièche I, Bright RK, Lidereau R, Chen Y and Byrne JA TPD52 represents a survival factor in ERBB2-amplified breast cancer cells. Mol Carcinog 53: 807-819, 2014.

34. Weir BA, Woo MS, Getz G, Perner S, Ding L, Beroukhim R, Lin WM, Province MA, Kraja A, Johnson LA, et al: Characterizing the cancer genome in lung adenocarcinoma. Nature 450: 893-898, 2007.

35. Rohrbeck A, Neukirchen J, Rosskopf M,Pardillos GG, Geddert H, Schwalen A, Gabbert HE, von Haeseler A, Pitschke G, Schott M et al: Gene expression profiling for molecular distinction and characterization of laser captured primary lung cancers. J Transl Med 6: 69, 2008.

36. Zhu H, Lam DC, Han KC, Tin VP, Suen WS, Wang E, Lam WK, Cai WW, Chung LP and Wong MP: High resolution analysis of genomic aberrations by metaphase and array comparative genomic hybridization identifies candidate tumour genes in lung cancer cell lines. Cancer Lett 245: 303-314, 2007.

37. Hanada S, Kakehashi A, Nishiyama N, Wei M, Yamano S, Chung K, Komatsu H, Inoue H, Suehiro S and Wanibuchi H: Myristoylated alanine-rich C-kinase substrate as a prognostic biomarker in human primary lung squamous cell carcinoma. Cancer Biomark 13: 289-298, 2013.

38. Boelens MC, van den Berg A, Fehrmann RS, Geerlings M, de Jong WK, te Meerman GJ, Sietsma H, Timens W, Postma DS and Groen HJ: Current smoking-specific gene expression signature in normal bronchial epithelium is enhanced in squamous cell lung cancer. J Pathol 218: 182-191, 2009.

39. Lewis JD, Payton LA, Whitford JG, Byrne JA, Smith DI, Yang L and Bright RK: Induction of tumorigenesis and metastasis by the murine orthologue of tumor protein D52. Mol Cancer Res 5: 133-144, 2007.
40. Ummanni R, Teller S, Junker H, Zimmermann U, Venz S, Scharf C, Giebel J and Walther R: Altered expression of tumor protein D52 regulates apoptosis and migration of prostate cancer cells. FEBS J 275: 5703-5713, 2008

41. Li L, Xie H, Liang L, Gao Y, Zhang D, Fang L, Lee SO, Luo J, Chen X, Wang X, et al: Increased PrLZ-mediated androgen receptor transactivation promotes prostate cancer growth at castration-resistant stage. Carcinogenesis 34: 257-267, 2013.

42. Takahashi Y, Forrest AR, Maeno E, Hashimoto T, Daub CO and Yasuda J: MiR-107 and MiR-185 can induce cell cycle arrest in human non small cell lung cancer cell lines. PLoS One 4: e6677, 2009.

43. Kaller M, Liffers ST, Oeljeklaus S, Kuhlmann K, Röh S, Hoffmann R, Warscheid B and Hermeking H: Genome-wide characterization of miR-34a induced changes in protein and mRNA expression by a combined pulsed SILAC and microarray analysis. Mol Cell Proteomics 10: M111 010462, 2011. doi: 10.1074/mcp.M111.010462.

44. Goto Y, Nishikawa R, Kojima S, Chiyomaru T, Enokida H, Inoguchi S, Kinoshita T, Fuse M, Sakamoto S, Nakagawa M, et al: Tumour-suppressive microRNA-224 inhibits cancer cell migration and invasion via targeting oncogenic TPD52 in prostate cancer. FEBS Lett 588: 1973-1982, 2014.

45. Han G, Fan M and Zhang X: microRNA-218 inhibits prostate cancer cell growth and promotes apoptosis by repressing TPD52 expression. Biochem Biophys Res Commun 456: 804-809, 2015.

46. Aarts M, Linardopoulos S and Turner NC: Tumour selective targeting of cell cycle kinases for cancer treatment. Curr Opin Pharmacol 13: 529-535, 2013

47. Dominguez-Brauer C, Thu KL, Mason JM, Blaser H, Bray MR and Mak TW: Targeting mitosis in cancer: Emerging strategies. Mol Cell 60: 524-536, 2015.

48. Liu X, Liao W, Yuan Q, Ou Y and Huang J: TTK activates Akt and promotes proliferation and migration of hepatocellular carcinoma cells. Oncotarget 6: 34309-34320, 2015.

49. Nyati S, Schinske-Sebolt K, Pitchiaya S, Chekhovskiy K, Chator A, Chaudhry N, Dosch J, Van Dort ME, Varambally S, Kumar-Sinha C, et al: The kinase activity of the Ser/Thr kinase BUB1 promotes TGF- $\beta$ signaling. Sci Signal 8: ra1, 2015.

50. Wu J, Ivanov AI, Fisher PB and Fu Z: Polo-like kinase 1 induces epithelial-to-mesenchymal transition and promotes epithelial cell motility by activating CRAF/ERK signaling. eLife 5: 5, 2016.

51. Lei CY, Wang W, Zhu YT, Fang WY and Tan WL: The decrease of cyclin B2 expression inhibits invasion and metastasis of bladder cancer. Urol Oncol 34: 237.e1-237.e10, 2016 